\title{
ESTIMATION OF CONSUMERS' WILLINGNESS TO PAY FOR CAVENDISH BANANA USING CONTINGENT VALUATION METHOD IN YOGYAKARTA SPECIAL REGION
}

\author{
Novia Dewi Karisyawati ${ }^{1}$, Any Suryantini ${ }^{2}$, Arini Wahyu Utami ${ }^{3}$ \\ ${ }^{1}$ Student of Postgraduate Program of Agribusiness Management, \\ Faculty of Agriculture, Universitas Gadjah Mada \\ ${ }^{2,3}$ Department of Agricultural Socioeconomics, Faculty of Agriculture, \\ Universitas Gadjah Mada \\ Jalan Flora, Bulaksumur, Depok, Sleman, Daerah Istimewa Yogyakarta \\ noviadk@mail.ugm.ac.id
}

Submitted : 25 September 2019 ; Revised : 16 November 2019; Accepted : 16

Desember 2019

\begin{abstract}
Banana is a fruit with the highest consumption level in Indonesia. There are many types of bananas in Indonesia, but only a few types are sold in modern markets and fruit shops, among other Cavendish banana. The Cavendish is known to consumers by their attractive appearance, superior quality and relatively higher prices. This study aims to assess the value of the consumers' willingness to pay (WTP) for Cavendish banana and its determinant factors. There were two methods used, i.e., contingent valuation method to evaluate the consumers' willingness to pay, and multiple regression to analyse its determinant factors. Primary data were obtained from 100 respondents by purposive sampling and interviewed in Yogyakarta Special Region between April and June 2019. The results indicate that the consumers' willingness to pay (WTP) for Cavendish banana was IDR $24,485 / \mathrm{kg}$, which was above the market price. The determinant factors of the consumers' willingness to pay included the Cavendish banana price, quality of the Cavendish, monthly frequency of consuming banana, family size, income and marital status. The high value of the consumers' willingness to pay indicates the good opportunity to expand the Cavendish banana market in Special Province Yogyakarta, by taking into account quality and market segmentation.
\end{abstract}

Keywords: Cavendish Banana, Contingent Valuation Method, Willingness to Pay

Karisyawati, N.D., Suryantini, A., \& Utami A.W. (2019) Estimation of Consumers' Willingness to Pay For Cavendish Banana Using Contingent Valuation Method in Yogyakarta Special Region. Agro Ekonomi 30(2), 167-181.

\section{INTRODUCTION}

Banana plants are widespread and play an important role in everyday life, bananas are a good source of potassium and carbohydrates for the body (Hapsari
\& Lestari, 2016). Bananas consist of two main species, namely Musa acuminate diploid genon (AA) and Musa balbisiana diploid genon (BB). The development of banana cultivation technology is 
more advanced so that it is able to produce the crossing of bananas that are desirable, one of which is Cavendish banana with the triploid genome (AAA). Cavendish bananas are easily found in the Indonesian market, especially in the modern market. The sustainable supply of bananas of the same quality is produced from intensive agriculture of industrial-scale (Suhartanto et al., 2014)

Modern markets and fruit shops are different from traditional markets. Traditional markets provide a variety of products according to each seller, on the contrary, modern markets only sell products that have high purchasing power according to segmentation. According to Eliza et al., (2011), consumers who go shopping at traditional markets say it is uncomfortable because there is a lot of rubbish causing odor. These environmental conditions make the quality of the fruit decreases due to exposure to the outside environment. Conversely, shopping in the modern market is more comfortable with adequate shopping facilities, clean and guaranteed quality.

Consumers' awareness of the purchase of healthy food products with high nutritional value is increasing. It leads consumers' willingness to pay for food products that are healthier, cleaner, have guaranteed quality and are certified at higher prices (Velčovská
\& Del Chiappa, 2015; Petjak et al., 2017). According to the food security bulletin focusing on consumer trends, the majority of Indonesia's population consumes fruits and vegetables as much as 173 grams per day, there are only three provinces namely Yogyakarta, Bali, and Central Sulawesi with per capita fruit consumption levels of more than 200 grams per day (BMKG, Kementerian Pertanian, BNPB, LAPAN, BPS, WFP, 2017). Based on these data, there are three potential provinces to study, one of them is Yogyakarta.

Yogyakarta Special Region was chosen as a research location because it has a heterogeneous population. The cause of the population diversity because this region known as studentss city, so that each community from various regions has different tastes of food. It makes Yogyakarta Special Region can be considered to represent Indonesia. The diversity of the population is expected to represent the lifestyle trends of people in Indonesia. According to Sumarwan (2011), lifestyle describes the external manifestation of consumers. A person's lifestyle is changing and easy to follow the times, lifestyle changes will change one's consumption patterns.

Research on consumer trends in purchasing foodstuffs carried out domestically and abroad. The results stated that consumers not only pay 
attention to taste and price when making a purchase, but also begin to prioritize the health and quality of the food. It changes the mindset of consumers to be willing to spend more money on purchasing high quality of food ingredients. Consumers state that it is better to consume vegetables and fruits that are more expensive but guaranteed in quality (Velčovská \& Del Chiappa, 2015; Rofiatin and Bariska, 2018). The results of previous studies state that the willingness to pay value of food products would be increasing when product quality was higher, product prices was low and large of consumer ncomes (Fathia et al., 2018; Rofiatin and Bariska, 2018; Velčovská \& Del Chiappa, 2015) prices were gotten higher, the willingness to pay value of fresh products increased with quality and high consumer income (Gumirakiza\&Choate, 2018; Petjak et al., 2017). Higher levels of education and consumer's employment types of have a positive effect on the willingness to pay of organic food products (Muhammad et al., 2015). According to Gumirakiza \& Choate (2018) married consumers had a higher willingness to pay value of fresh products and women have a lower willingness to pay value than men. In contrary, the research done by Eliza et al. (2011) and Alphonce et al., (2015) states that women were willing to pay far more than men because women as decision makers in the household. The frequency factor of banana consumption and the number of family members also affected the willingness to pay value of fresh product. Based on the previous research, there were internal and eksternal factors influencing the consumers' willingness to pay food product.

Purchase of an item cannot be separated from price agreements between producers and consumers. This also applies to Cavendish banana, the price offered is relatively more expensive compared to other banana prices, but the demand of Cavendish banana remains high. The high demand of Cavendish banana is an interesting issue to study, because it allows us to find out how much the consumers' willingness to pay Cavendish banana whether below or above the price offered by the market. Not only knowing the value, but also what factors interfering the consumers' willingness to pay Cavendish banana. The managerial implication of this research will provide information about potential future sales through the average value of consumers' willingness to pay of Cavendish banana. In addition, this study also provides information about social demographic factors that influence the value of consumers' willingness to pay of Cavendish banana, in order for the 
producer and distributor to can find the right consumer segmentation. Research on consumers' willingness to pay for Cavendish banana is interesting because it has never been done in Indonesia, especially in Yogyakarta Special Region.

\section{METHODS}

This research was conducted at Hypermart, fruit shops, sports venues and educational institutions located in Yogyakarta Special Region, with Purposive Sampling. The sampling method used was non-probability convenience sampling. Specifically with the incidental technique, which means the respondent was every visitor shopping for fruit at Hypermart and the fruit shop, or was exercising, active in an educational institution and willing to be interviewed. Data collection took place from April to June 2019 with 100 respondents. The number of respondents were obtained from 10 times the total independent variables. According to Sugiyono (2015), sampling size should be at least 10 times the number of variables for research with multivariate analysis (correlation or multiple regression).

The data collected in the form of primary data were obtained directly from the object of research, the results of interviews with respondents, as well as observations made with observations of the research area. While secondary data were obtained from references and literature related to research objects that are outside the research area. Data collection was carried out using a survey method with a research instrument in the form of a questionnaire made in the form of a likert scale question.

In this study, there were two methods of data analysis namely the Contingent Valuation Method (CVM) and multiple regression analysis. Contingent Valuation Method (CVM) was used to determine the maximum willingness to pay (WTP) value that consumers are willing to pay for Cavendish banana as well as multiple regression analysis to find out what consumer characteristics factors influence the consumers' willingness to pay. The contingent valuation method was used to ask the maximum value consumers are willing to pay for the quality improvement they get. The stages in conducting CVM (Hanley et al., 2009) :

\section{Building a Hypothetical Market}

The Cavendish Banana Hypothetical Market illustrates the increasing public interest in fruits, one of which is that bananas are triggered by increasing public awareness of the importance of healthy living. Most people assume that eating banana is a source of potassium that is healthy, safe, 
and also nutritious and rich in vitamins and minerals especially potassium. Bananas are a source of potassium (K) can maintain body water balance, blood pressure, and heart function.

\section{Estimating Bid Value}

Bid values were obtained through direct interviews with respondents. The technique used was the open-ended question and the bidding game method. This open-ended question was used for Cavendish banana price data for each respondent. Then proceeded with the bargaining technique (bidding game), the respondent would be given a starting point (price starting point) and raise to the maximum payment point.

\section{Estimating Average WTP Value}

The average value of WTP was obtained from a collection of respondents' answers regarding the price of Cavendish banana. The averaoe was calculated using the follonEWTP $=\sum_{i=1}^{n} W_{i}\left(f_{i}\right)$

Information:

$$
\begin{aligned}
\text { EWTP = } & \text { Alleged value of the average } \\
& \text { WTP of all respondents } \\
\mathrm{W}_{\mathrm{i}} \quad & \text { WTP value of the respondent } \\
& \mathrm{i}(\text { IDR }) \\
\mathrm{f}_{\mathrm{i}} \quad & \text { The relative frequency of the } \\
& \text { WTP class of respondent } \mathrm{i}
\end{aligned}
$$

I = The i-respondent who is willing to pay $(\mathrm{i}=1,2, \ldots . ., 100)$

\section{Estimating the Bid Value Curve}

The WTP value curve (bid curve) of respondents was formed using the cumulative amount of each individual who chooses a particular WTP value. The curve relationship illustrates the level of WTP who were willing to be paid by the number of respondents who were willing to pay. Assumptions were individuals who were willing to pay a certain value for a number that is getting less or more parallel to the value of the WTP.

\section{WTP Total Data Aggregation}

Aggregation of total WTP data is obtained by using the average value of WTP converted to population. Calculation of total WTP uses the following equation:

$$
\text { TWTP }=\mathrm{EWTP} \times P O P
$$

Information:

$$
\begin{aligned}
\text { TWTP }= & \text { Total value of WTP (IDR) } \\
\text { EWTP = } & \text { Estimated value of the average } \\
& \text { WTP of all respondents } \\
\text { POP = } & \text { Population (people) }
\end{aligned}
$$

The analysis used to determine the factors that influence the value of banana WTP was multiple linear regression. There were 10 independent variables that were expected to affect the WTP value of Cavendish banana in Special 
Province Yogyakarta. Estimating these factors was based on previous research and direct observation. The multiple linear regression analysis model used in this study, namely:

ln $Y=\operatorname{Ln} b_{0}+b_{1} \operatorname{Ln} X_{1}+b_{2} \operatorname{Ln} X_{2}+b_{3} \operatorname{Ln} X_{3}+$ $b_{4} \operatorname{Ln} X_{4}+b_{5} \operatorname{Ln} X_{5}+b_{7} D_{1}+b_{8} D_{2}+b_{9} D_{3}+$ $b_{10} D_{4}+e$

Information:

$\mathrm{Y}=$ WTP Cavendish

$\mathrm{X}_{1}=$ Cavendish banana prices (IDR)

$\mathrm{X}_{2}=$ Cavendish banana quality

$\mathrm{X}_{3}=$ Frequency of consumption banana (x/month)

$\mathrm{X}_{4}=$ Respondent's income/month (IDR)

$\mathrm{X}_{5}=$ Family size (Person)

$\mathrm{X}_{6}=$ Education (Years)

$\mathrm{D}_{1}=$ Marital Status $(1=$ Married, $0=$ Unmarried)

$\mathrm{D}_{2}=$ Type of Employment (1=Formal Employee, = Informal Employee)

$\mathrm{D}_{3}=$ Lifestyle (1=Healthy Lifestyle, by consuming fruit every day, $0=$ Unhealthy Lifestyle)

$\mathrm{D}_{4}=$ Gender (=Female, $0=$ Male $)$

\section{RESULTS AND DISCUSSION}

Respondents were scattered in three regencies in Yogyakarta Special Region, most of them were domiciled in Sleman (40\%) the rest are in the cities of Yogyakarta and Bantul. Among the respondents, the dominant average income was IDR1,000,000-3,500,000 per month (72\%). The majority of respondents were women $(71 \%)$, age range 18-25 years (52\%), unmarried (71\%), and with a small number of family members, 1-4 people $(85 \%)$. These characteristics of respondents were more directed to the lifestyle of the younger generation. This is proven by $43 \%$ of all respondents who prefered shopping in comfortable supermarkets, and those having a healthy lifestyle by consuming fruit every day (48\%). Respondents had a minimum frequency of consumption of bananas 1-4 times/month (53\%) with the main reason for purchasing was with regards to health (51\%) abd the rest was because it had good tastes and could be consumed practically.

\section{Analysis of the Willingness to Pay Value of Cavendish Banana}

Based on the survey, it was found that as many as $82 \%$ of respondents were willing to pay for Cavendish banana at a price of more than IDR $20,000 / \mathrm{kg}$. Their willingness to pay above market prices was based on belief and confidence in Cavendish banana for health. Respondents believe that Cavendish banana were a source of potassium, good for the digestion system, as well as food intake that is quickly processed by the body. There were $37 \%$ of female respondents aged 
18-25 years making Cavendish banana food for their diet, as a substitute for breakfast and food before exercising. The knowledge of these respondents is in line with Hapsari et al. (2017), that bananas are a source of potassium carbohydrates and vitamin $\mathrm{C}$ with low fat content so that it is good as a diet menu.

\section{Cavendish Banana Hypothetical Market}

The hypothetical market helped consumers recognize the benefits of bananas as a source of vitamins and minerals. Respondents obtained information about the characteristics of the product to the benefits they have when consuming Cavendish banana. Based on interviews, Cavendish banana was perceived as fruits containing vitamins $\mathrm{A}$, $B, C$ and a source of potassium. Given the fact that $48 \%$ were respondents with a healthy lifestyle, meaning that $48 \%$ of all the population D.I. Yogyakarta care about health, one of them by consuming fruit every day. This statement is consistent with the trend of consumption and production of fruits and vegetables (2017) that in D.I. Yogyakarta the average value of consuming 200 grams of fruit/day exceeds the average consumption rate of Indonesian population which is 173 grams/day.

\section{Cavendish Banana WTP Value}

The starting point for determining Cavendish Banana WTP value was IDR 20,000/kg. Based on survey in D.I. Yogyakarta, the Cavendish banana WTP value was between IDR 20,000$30,000 / \mathrm{kg}$ (85\%). The lowest WTP value explaining willing to be paid for Cavendish banana per kilogram was IDR $15,000 / \mathrm{kg}$, while the highest value was IDR 50,000/kg.

The desire of consumers to pay more than the actual price supposedly due to the location of product purchases. About $43 \%$ of respondents shopped Cavendish banana at the supermarket, one of which was Hypermart. The location of product purchases led to its segmentation, for Hypermart was a shopping location for the upper middle class. Respondents believed that good quality fruit should be given a fair price.

\section{WTP Average Value}

The average value of Cavendish banana WTP in Yogyakarta was IDR $24.485 / \mathrm{kg}$. This value is higher than the average market price of IDR 20,000/kg. The average value indicates that there is a consumer surplus because the WTP value desired by respondents is higher than the average WTP value, which was IDR $24,485 / \mathrm{kg}$. The results show that Cavendish banana had a high selling power. The selling power provides an opportunity that Cavendish banana can 
penetrate the market in D.I. Yogyakarta with prices that are much higher than now, but must go hand in hand with the promised quality. Good quality includes physical appearance, whether in skin color, minimal black spots and no bruises (Moser et al., 2011)

\section{WTP curve}

Respondents' WTP curves were formed using the cumulative amount of the number of respondents who give a certain WTP value. The assumption is that the higher the WTP price offered, the lower the number of respondents who were willing to pay Cavendish banana,at the price. Figure 1 explains the relationship between the Cavendish banana WTP level and the number of respondents who are willing to pay. The results of the Cavendish Banana WTP curve plot show that most respondents had a WTP value of between IDR 20,000-25,000. The plot results represented the respondent demand curve for Cavendish banana in D.I. Yogyakarta.

\section{WTP Total Data Aggregation}

The aggregate value of WTP is useful for providing information about the value of sales at the maximum price that consumers are willing to pay. The total value of Cavendish banana WTP in D.I. Yogyakarta was obtained from

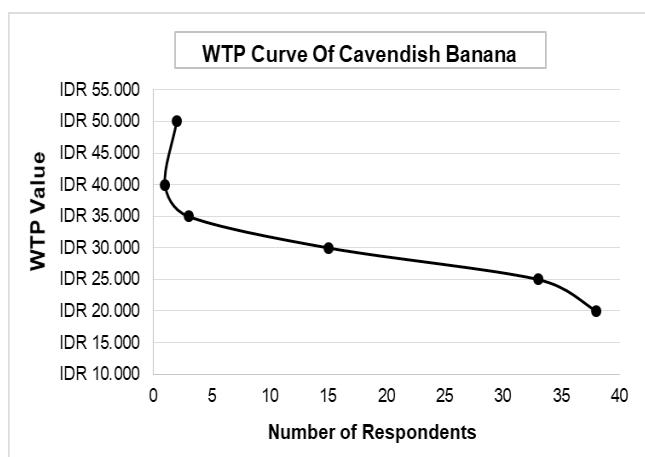

Figure 1. Cavendish Banana WTP Curve Source: Primary Data (2019)

the Cavendish EWTP value multiplied by the population of Yogyakata, so that TWTP was IDR 91.106.530.320. This aggregated value enabled marketers to see potential market that can be developed from the determination of the average value of consumers' willingness to pay Cavendish banana in D.I. Yogyakarta.

\section{The Determinant Factors on Cavendish}

\section{Banana WTP}

The multiple regression results show that without any affecting variables, the Cavendish Banana WTP value was IDR 144 /kg. The Cavendish banana WTP value would increase until it reached an average value of IDR $24,485 / \mathrm{kg}$ because it was influenced by the variables in the model. There were six variables that have a significant influence on the value of WTP, namely Cavendish banana prices commonly paid by respondents, family size, income levels, Cavendish banana quality, frequency of banana 
consumption and marital status (Tabel 1).

\section{Cavendish Banana Prices}

Cavendish banana prices had a positive effect on the value of WTP, when there is an increase in the price of Cavendish banana by $1 \%$, it will increase the value of WTP by $0.29 \%$. Increasing the price of a product will usually reduce consumer interest to make a purchase but not for some products that have added value and the status of products, such as imported products, have a special attraction in the Indonesian market (Muhammad et al., 2015 ; Velčovská \&
Del Chiappa, 2015). There were variables other than quality that affect WTP such as the status of imported products, this status has a special attraction in the Indonesian market (Muzdalifah, 2012). There is an assumption that the development of high value foodstuffs such as organic food is not expensive but inorganic foodstuffs have too low prices (Petjak et al., 2017). This can be applied to bananas. Cavendish banana having an attractive appearance such as imported products with clean yellow skin and a package sold relatively less is not expensive, but bananas that have

Table 1. The Determinant Factors of Consumers' willingness to pay Cavendish Banana

\begin{tabular}{lclc}
\hline \multicolumn{1}{c}{$\begin{array}{c}\text { Ln Y (Cavendish } \\
\text { Banana WTP) }\end{array}$} & Expected sign & $\begin{array}{l}\text { Regression } \\
\text { Coefficients }\end{array}$ & t-Statistic \\
\hline Constant & + & $4.97^{* * *}$ & 3.61 \\
Ln Price & - & $0.29^{* * *}$ & 2.48 \\
Ln Quality & + & $0.97^{* * *}$ & 4.28 \\
Ln Frequency of & + & $0.07^{* * *}$ & 3.24 \\
Banana Consumption & & & \\
Ln Income & + & $0.07^{* *}$ & 2.22 \\
Ln Family Size & - & $0.06^{* *}$ & 2.03 \\
Marital status & + & $-0.22^{* * *}$ & -3.76 \\
Ln Education & + & -0.09 & -0.51 \\
Types of Employment & + & -0.01 & -0.32 \\
Lifestyle & + & 0.01 & 0.26 \\
Gender & + & 0.02 & 0.54 \\
F-Statistic & & $4.51^{* * *}$ & \\
$\mathrm{R}^{2}$ & & 0.34 & \\
Durbin-Watson & & 1.89 & \\
\hline
\end{tabular}

Notes :

*) Significant at the level 90\% $(\alpha=10 \%$, t table $=1.6622)$

**) Significant at the level 95\% $(\alpha=5 \%$, t table $=1.9869)$

***) Significant at the level $99 \%(\alpha=1 \%$, t table $=2.6322)$

Source: Primary Data (2019) 
the usual appearance and are sold in one comb are too cheap.

\section{Quality of Cavendish Banana}

Product quality is related to product prices, while high prices are proportional to the quality provided. Product quality has a significant positive impact on the value of WTP, the results of the study state that a better quality of $1 \%$ can increase the WTP value of Cavendish banana by $0.97 \%$..

The average consumer preference reveals that the quality of bananas contributed nearly $60 \%$ of the total importance of all attributes (Dhamotharan et al., 2015). The taste quality of food is the five main factors that influence the selection of consumers of a food product (Fathia, 2018). The quality of the fruit is not only the taste, but includes attractive appearance, strong aroma, sweet taste, non-flaccid texture and freshness guaranteed to increase fruit WTP and vegetables (Moser et al., 2011)

\section{Frequency of Banana Consumption}

Frequency of banana consumption variable was a fairly new factor in determining factors that affect WTP. The frequency of consumption is related to the amount of each respondent consuming bananas/month. The results of multiple regression analysis show that there was a significant positive relationship, indicating that the higher $1 \%$ the frequency of consuming bananas/ month by respondents, the higher the WTP value of Cavendish banana by $0.07 \%$. Respondents who consumed banana more often were able to give a higher appreciation of the product. This appreciation is reflected by giving a much more higher WTP value. According to Eliza et al., (2011), the frequency of consumption of a food product for each person varies depending on their needs and income. The results of this study indicate that $62 \%$ of respondents earning IDR 1,000,000-3,300,000 had a frequency of banana consumption 1-4 times/month while respondents with higher incomes of IDR 3,400.00$6,100,000$ tended to consume bananas 12 times/month.

\section{Income}

Income had a significant positive effect on Cavendish banana WTP value in D.I.Yogyakarta. When there is an increase in income by $1 \%$, the value of WTP will increase by $0.07 \%$. The higher the income, the higher the purchasing power of a consumer. This is consistent with the existing literature that high income carries high value of WTP for food products. (Velčovská \& Del Chiappa, 2015). The regression results were due to the average respondent's income of IDR 3,395,000 above the D.I.Yogyakarta's 
minimum wage. Respondent income was above the minimum wage, meaning that respondents can meet their daily needs, including buying fruit.

\section{Number of family members}

The variable family size usually has a negative influence, but in this study, increasing one family member will increase the WTP of Cavendish banana by $0.06 \%$. This research is in line with Croatia and the United Arab Emirates stating that a large number of family members will increase the WTP of food products (Petljak et al., 2017; Muhammad et al., 2015). A bigger number of household members might have higher monthly household income. They were having a value of willingness to pay Cavendish banana higher than the smaller number of household member. Married consumers were usually associated with an increased number of family members, but the results of this study were contrary. The result was that marital status decreased the value of willingness to pay, while large family members increased the value of willingness to pay. Marital status caused a greater burden if the husband or wife was unemployed, so married consumers did not always have a higher monthly household income compared to unmarried consumers and bigger number of household members. This is evidenced that unmarried respondents with family members of 3-4 people increased by $52 \%$, while married respondents with family member having 3-4 experienced increase by $48 \%$, so the future research is suggested to add mediation variables monthly household income

\section{Marital status}

The results of the analysis state that when a person was married, the value of his/her WTP was reduced by $0.22 \%$. This result contradicts the previous studies, that respondents who are married have a higher WTP value (Toma, 2014). According to alrakiza \& Choate, (2018), respondents who are married have raised concerns about the purchase of fresh products so that they have a higher WTP. These are opportunities to target married respondents in healthy food product market segmentation (Yuhanin, et al., 2019). The difference between the results of the research with the literature is because every person who is married has a different burden than those who are unmarried, so the budget allocation for fruit purchases adjusts the income of each respondent. Every family member has different tastes in consuming fruit. The taste that makes each family chooses to buy fruit that is suitable for the whole house. The statement about married respondents having health concerns is 
true, so that leads consumers to consume various kinds of fruit not just Cavendish banana. Diversification of consumption was one of the factors to reduce the WTP value of Cavendish banana.

\section{Insignificant Variables}

There were four insignificant factors namely education, type of work, lifestyle and gender. Respondents with higher education better understand the market price for Cavendish bananas so they did not buy the banana with too expensive prices. Based on data from $90 \%$ of respondents who have education above high school, it is assumed to be able to provide an assessment of prices. According to Sumarwan (2015), education will determine the type of work a person does, if one does not affect other factors usually do not affect. Regression results of lifestyle variable indicate that the non-significant value did not mean that someone who had a healthy lifestyle by consuming fruit every day did not want to buy Cavendish banana, instead they executed diversify their consumption. In general, WTP for food products such as horticulture increase when consumers' lifestyles are healthy, but this does not necessarily apply to specific commodities such as Cavendish banana. This tendency is made possible by fruit substitution so that the commodity specific WTP value is lower. In Table 1, it can be seen that gender did not significantly influence WTP value. Research in the United Arab Emirates states that gender did not affect the WTP value of a food product (Muhammad et al., 2015). Decision makers for shopping were not just women. Modern markets and fruit shops were convenient places and offer fixed prices, both of these factors could cause men to have the same opportunities in shopping for food products.

\section{CONCLUSIONS AND SUGGESTIONS}

The results show that consumers' willingness to pay for Cavendish banana in D.I. Yogyakarta was classified as high because the majority of the WTP values were obtained above the market price. The higher the price and the better the quality of Cavendish banana, the more the consumer consume the Cavendish, the higher the monthly income, and the bigger the family size the higher the willingness to pay of Cavendish banana. On the other hand, those who were married were more likely to have lower willingness to pay. The variables of gender, education, occupation and lifestyle did not influence the WTP value of Cavendish banana.The high average value of the WTP indicates that there was still a big opportunity to increase Cavendish banana sales volume in D.I. 
Yogyakarta by taking into account the quality and market segmentation.

The results of contingent valuation method found that there was a Cavendish banana consumer surplus of IDR 4,485/ $\mathrm{kg}$. Efficiency in the producing and marketing of Cavendish bananas needs to be maintained by producers so that people continue to benefit from the price surplus. This is able to to increase sales volume thereby increasing a healthy lifestyle can be done by consuming fruit such as Cavendish banana. Cavendish banana consumers in D.I. Yogyakarta understand that quality was proportional to price so it is recommended for producers and traders to do grading and sorting. Quality control is able to be improved quality, by grouping banana size, maturity and freshness. Consumers had an average income above regional minimum wage at D.I.Yogyakarta. Highincome consumers would increase the frequency of consumption of Cavendish bananas, so it is recommended that the availability of Cavendish bananas on the market always follows the high demand.

\section{BIBLIOGRAPHY}

Alphonce, R., Temu, A., and Almli, V.L.(2015). European Consumer Preference for African Dried Fruits. British Food Journal. 117(7):18861902.
BMKG, Kementerian Pertanian, BNPB, LAPAN, BPS, WFP, F. (2017). Buletin Pemantauan Ketahanan Pangan Indonesia. German Humanitarian Assistance, 8(November), 1-24. Retrieved from https://docs. wfp.org/api/documents/WFP0000024091/download/

Dhamotharan, P. G., Devadoss, S., \& Selvaraj, K. N. (2015). Estimation of Consumers' Willingness to Pay for Geographic Indications Bananas Using Conjoint Analysis. Journal of International Food and Agribusiness Marketing, 27(2), 65-78. https://doi.org/10.1080/ 08974438.2013 .833574

Eliza, Sayamar, E. and Kaswita, Cory.2011.Analisis Faktor-Faktor Yang Memengaruhi Konsumen Dalam Pengambilan Keputusan Pembelian Buah Di Pasar Arengka (Pasar Tradisional Dan Giant Hypermarket (Pasar Modren) Di Kecamatan Tampan Kota Pekanbaru. Indonesian Journal of Agricultural Economics (IJAE) Vol 2:15-34.

Fathia, Q. N., Nurmalina, R., \& Simanjuntak, M. (2018). Consumer's Attitude and Willingness to Pay for Organic Rice. Indonesian Journal of Business and Entrepreneurship, 4(1), 11- 
21. https://doi.org/10.17358/ ijbe.4.1.11

Gumirakiza, J. D., \& Choate, T. (2018). The Willingness to Pay for Local, Domestic, and Imported Bundled Fresh Produce by Online Shoppers. Journal of Agricultural Science, 10(12), 15. https://doi. org/10.5539/jas.v10n12p15

Hanley, Nick and Barbier, Edward B.2009. Pricing Nature Cost Benefit Aanalysis and Environment Policy.USA: Edward Elgar Publishing Company

Hapsari, L., Kennedy, J., Lestari, D. A., Masrum, A., \& Lestarini, W. (2017). Ethnobotanical Survey of Bananas (Musaceae) in Six Districts of East Java, Indonesia. Biodiversitas, 18(1), 160-174. https://doi. org/10.13057/biodiv/d180123

Hapsari, L., \& Lestari, D. A. (2016). Fruit Characteristic and Nutrient Values of Four Indonesian Banana Cultivars (Musa spp.) at Different Genomic Groups. Agrivita, 38(3), 303-311. https://doi. org/10.17503/agrivita.v38i3.696

Moser, R., Raffaelli, R., \& ThilmanyMcFadden, D. (2011). Consumer Preferences for Fruit and Vegetables with Credence-Based Attributes: A Review. International
Food and Agribusiness Management Review, 14(2), 121-142.

Muhammad, S., Fathelrahman, E., \& Ullah, R. U. T. (2015). Factors Affecting Consumers' Willingness to Pay for Certified Organic Food Products in United Arab Emirates. Journal of Food Distribution Research, 46(1), 37-45. Retrieved from http:// search.ebscohost.com/login.aspx ?direct=true \&db=bth\&AN=10915 $5789 \&$ site $=$ ehost-live $\&$ scope $=$ site

Muzdalifah. (2012). Kajian Preferensi Konsumen Terhadap Buah-Buahan Lokal di Kota Banjarbaru. Jurnal Agribisnis Perdesaan, 02(04), 297309

Petljak, K., Štulec, I., and Renko, S.(2017). Consumers' Willingness To Pay More For Organic Food In Croatia. Ekonomski Vjesniks. 30(2): 441-455

Rofiatin, U., \& Bariska, H. F. (2018). Pola Willingnes To Pay (Wtp) Dan Faktor - Faktor Yang Mempengaruhi Terhadap Pilihan Sayur Organik Dan Anorganik Masyarakat Kota Malang. Optima, 2(1), 18. https:// doi.org/10.33366/opt.v2i1.898

Sugiyono.2015. Metode Penelitian Kuantitatif, Kualitatif, dan R\&D. Cetakan ke-22. Bandung: Alfabeta. 
Suhartanto, R., Sobir, \& Harti, H. (2014). Buku Ajar Teknologi Sehat Budidaya Pisang. In Buku Ajar Ilmu Penyakit Dalam.

Sumarwan, Ujang. (2011). Perilaku Konsumen Teori dan Penerapannya Dalam Pemasaran, Edisi 2. Bogor: Ghalia Indonesia

Toma, E. (2014). Food Purchase Behaviors for Low, Medium and High Income Families. International Journal of Academic Research in Environment and Geography, 1(2), 33-39. https://doi.org/10.6007/ IJAREG/v1-i2/1450
Velčovská, Š., \& Del Chiappa, G. (2015). The Food Quality Labels: Awareness and willingness to Pay in The Context of the Czech Republic. Acta Universitatis Agriculturae et Silviculturae Mendelianae Brunensis, 63(2), 647658. https://doi.org/10.11118/ actaun201563020647

Yuhanin, Zamrodah, Y., Koestiono, D., Setiawan, B., \& Syafrial. (2019). Consumer Characteristics Related To Willingness To Pay for Organic Rice. Russian Journal of Agricultural and Socio-Economic Sciences, 89(5), 76-84.https://doi.org/10.18551/ rjoas.2019-05.10 